\title{
An Isolated Tracheal Papilloma: A Case Report
}

\author{
Izole Trakeal Papillom: Olgu Sunumu
}

Ceyda Anar', Onur Fevzi Erer' ${ }^{1}$, Melike Yüksel Yavuz' ${ }^{1}$ Nur Yücel ${ }^{2}$

\begin{abstract}
A 32-year-old male patient with a history of 10-packyear smoking and prolonged intubation due to childhood meningitis was admitted with hemoptysis and dyspnea. Thoracic computed tomography showed that a $6 \times 9-\mathrm{mm}$ soft tissue lesion, extending from the tracheal wall of the right tracheal lumen. The rigid bronchoscopy revealed two separate lesions: the first one was a $1-\mathrm{cm}$ granulation tissue located at the anterior tracheal wall at the level of second tracheal ring, and there appeared a 2 to $3-\mathrm{cm}$ grape-like fragile lesion $3-\mathrm{cm}$ below the first lesion. The lesions were resected with electrocautery and Argon plasma coagulation, and treated with balloon dilatation. The histopathological diagnosis was reported as a tracheal papilloma. Clinicians must have a high index of suspicion for tracheal papillomatosis in patients with hemoptysis and obstructive symptoms along with a tracheotomy history.
\end{abstract}

Key words: : Trachea, HPV-6, papilloma.
Özet

Öyküsünden on paket/yıl sigara içicisi ve çocukluk çağında geçirdiği menenjit sonrasında uzamış entübasyona bağlı trakeostomi açıldığı öğrenilen 32 yaşında erkek hasta, hemoptizi ve nefes darlı̆̆ı yakınması ile başvurdu. Toraks bilgisayarlı tomografisinde trakeal duvardan trakeal lümenin sağ tarafına doğru uzanan 6X9 mm çapında yumuşak doku izlendi. Riiid bronkoskopisinde iki ayrı lezyon görüldü. Trakea ikinci halka hizasında anteriorda $1 \mathrm{~cm}^{\prime} l i k$ alanda pasajı \%90 daraltan granülasyon dokusu gözlendi. Yaklaşık $3 \mathrm{~cm}$ sonra orta bölüm posteriorda 2-3 cm'lik alanda kanamaya meyilli, üzüm salkımı şeklinde bir kitle izlendi. Bu lezyondan $3 \mathrm{~cm}$ sonraya kadar trakea normal idi. Lezyonlara elektrokoter, argon plazma koagülasyon, rezektör balon dilatasyon ve desobstrüksiyon yapıldı. Patoloji sonucu papillom ile uyumlu olarak geldi. Uzun süre trakeostomi öyküsü olan, hemoptizi ve obstrüktif semptomlarla başvuran hastalarda trakeal papillomatozisden şüphelenilmelidir.

Anahtar Sözcükler: Trakea, HPV-6, papillom.
A tracheal papilloma (TP) is characterized by the papillomatous growth of the bronchial epithelium which involves the trachea as a response to Human Papilloma Virus (HPV) infection. Most cases of TP are due to HPV-6 and HPV-1 1 ; however, HPV16 and HPV-18 have been also typed in some cases of bronchial and TPs. The latter subtypes are usually associated with poor outcomes (1).
The management includes repeated bronchoscopic interventions and medical treatment regimens. It should be closely followed, as malignant transformation has been reported in smokers, particularly. Herein, we report a 32-year-old male case of TP with a history of 10-pack-year smoking and, prolonged intubation due to childhood meningitis who was admitted with hemoptysis and dyspnea.

'Department of Chest Diseases, Dr. Suat Seren Chest Diseases and Surgery Training and Research Hospital, İzmir, Turkey ${ }^{2}$ Department of Pathology, Dr. Suat Seren Chest Diseases and 'İzmir Dr. Suat Seren Göğüs Hastalıkları ve Cerrahisi Eğitim Araştırma Hastanesi, Göğüs Hastalıkları Bölümü, İzmir ${ }^{2} j_{z m i r}$ Dr. Suat Seren Göğüs Hastalıkları ve Cerrahisi Eğitim Surgery Training and Research Hospital, İzmir, Turkey Araştırma Hastanesi, Patoloji Bölümü

Submitted (Başvuru tarihi): 02.01.2016 Accepted (Kabul tarihi): 27.04.2016

Correspondence (iletişim): Ceyda Anar, Department of Chest Diseases, Dr. Suat Seren Chest Diseases and Surgery Training and Research Hospital, İzmir, Turkey

e-mail:drceydaanar@hotmail.com

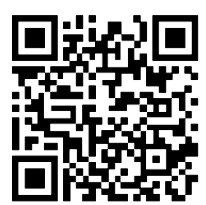




\section{CASE}

A 32-year-old, active smoker male presented with hemoptysis and dyspnea for the past two months. He was diagnosed with chronic obstructive pulmonary disease (COPD) and used bronchodilator treatment for one year. He had a history of prolonged intubation, and tracheostomy was opened due to childhood meningitis, and tracheostomy was closed after months. Laboratory tests and chest $X$-ray findings were normal. Respiratory function test results were as follows: forced vital volume in one seconds (FEV1) 73\% (3.03 mL), forced vital capacity (FVC) $89 \%(4.41 \mathrm{~mL})$, and FEV1/FVC 84\%, and also plateaus were present in the inspiratory limb of the flow volume loop. On thoracic computed tomography (CT), irregular contours in the trachea and also $6 \times 9 \mathrm{~mm}$ soft tissue lesion, extending from the tracheal wall of the right tracheal lumen were seen (Figure $1 \mathrm{a}$ and b). Rigid bronchoscopy (RB) revealed two separate lesions. The first one was a $1-\mathrm{cm}$ granulation tissue located at the anterior tracheal wall at the level of second tracheal ring. There appeared a $2-3 \mathrm{~cm}$ grape-like fragile second lesion $3-\mathrm{cm}$ below the first one (Figure 2). Electrocautery, argon plasma coagulation, and balloon dilatation were performed. The histopathological diagnosis was reported as a tracheal papilloma (Figure 3). The tracheal papilloma was positive for type 6 and negative for type 16 of human papilloma virus. At one month of treatment, CT showed no recurrence (Figure 4a, 4b). At six months of follow-up, the patient was asymptomatic and bronchoscopy findings were normal.
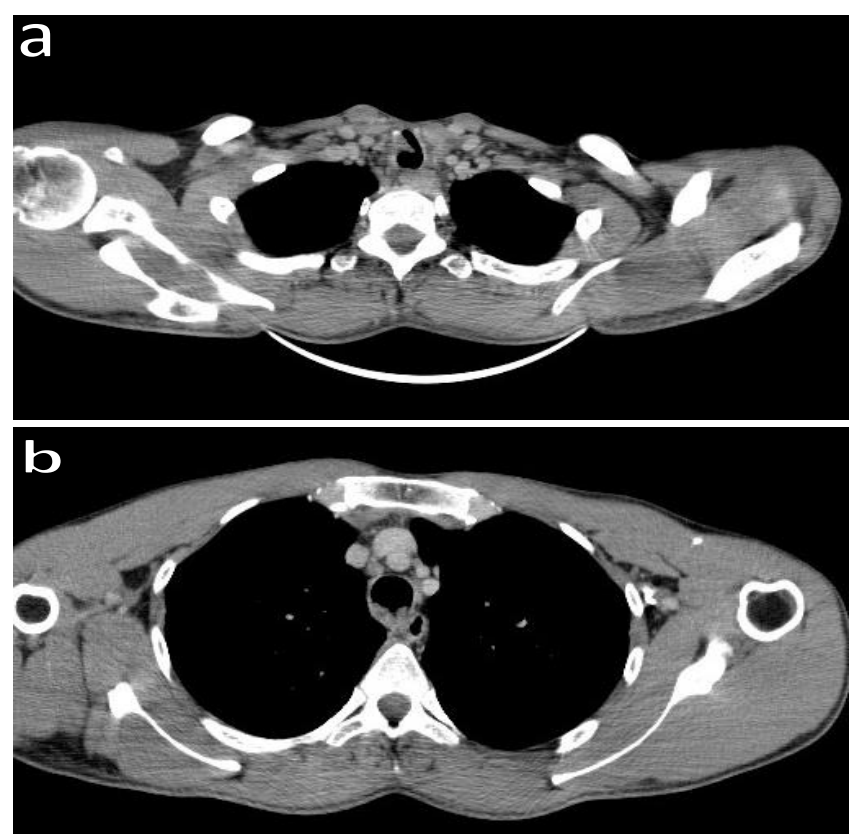

Figure 1 and b: Thoracic computed tomography showing a soft tissue lesion, extending from the tracheal wall

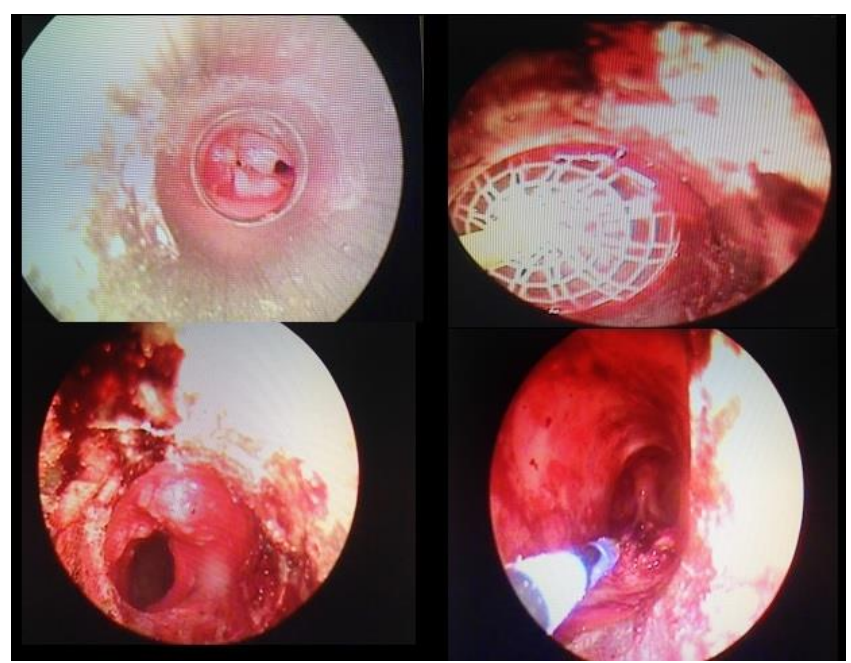

Figure 2: A bronchoscopic view of the lesion

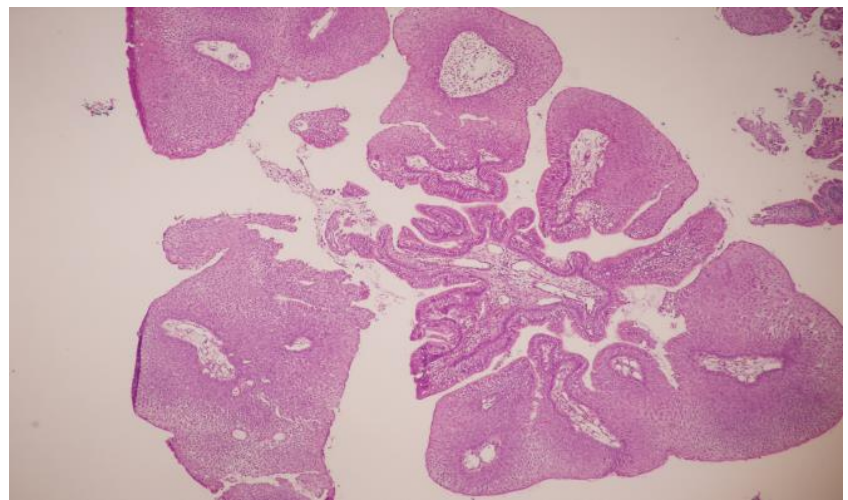

Figure 3: Histopathologic examination of papillomatozis lesion (HE X40)

\section{DISCUSSION}

A tracheal papilloma is a rare tumor of trachea consisting of $0.38 \%$ of all lung tumors (1). It can be solitary, multiple or as a few of recurrent respiratory papillomatosis (RRP). Respiratory papillomatosis is mostly seen in the larynx, although it can affect any part of the transbronchial tree. It is rarely located in the trachea. Distal trachea involvement was reported only in the $5 \%$ of RRP cases. In a study, TP was reported in only five cases of 15,000 bronchoscopies $(2,3)$. In our case, two separate lesions were seen in the RB. The first one was a $1-\mathrm{cm}$ granulation tissue located at the anterior tracheal wall at the level of second tracheal ring. There appeared a 2-3 cm grapelike fragile second lesion $3-\mathrm{cm}$ below the first one. There were no other tracheal or endobronchial lesions.

Tracheal papillomas present in two forms; the juvenileonset (JO) or adult-onset ( $\mathrm{AO}$ ). The $\mathrm{AO}$ type affects males and females at a ratio of $4: 1$. Tracheal papillomas can present at any age and is reported in all ethnicities. Our case was a 32-year-old male. Although rare reports of HPV transmission after cesarean delivery are available, the main mechanism of transmission in $\mathrm{JO}$ disease is 
thought to be due to a vertical transmission of the virus after vaginal delivery of an infected mother (4). It is unclear whether sexual contacts or latent viral activation is the principal way of HPV transmission in $\mathrm{AO}$ respiratory papillomatosis. latrogenic factors, such as laryngoscopy, bronchoscopy, tracheostomy or surgical manipulation, can also cause dissemination of papillomas to the distal portion of the tracheobronchial tree (5). Our case had no prior history of RRP in his childhood or maternal history of HPV. However, he had a history of prolonged intubation during childhood meningitis.
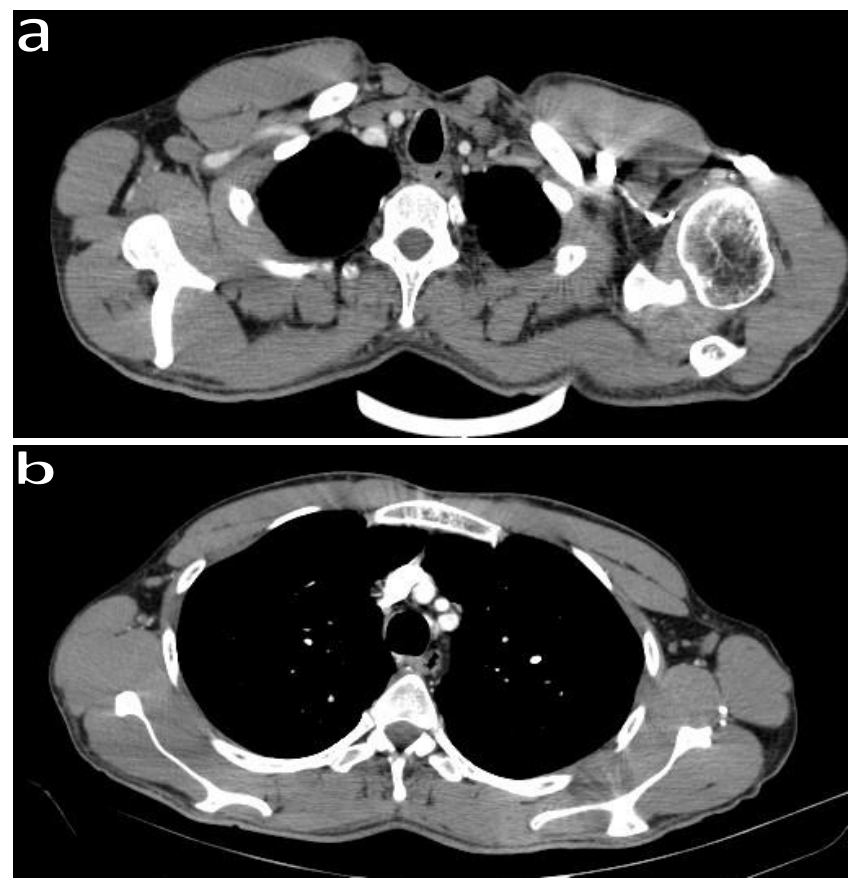

Figure 4 and $b$ : A computed tomography scan at one month of the treatment

The clinical presentation of TP is non-specific. Symptoms range from cough and dyspnea to stridor and upper airway obstruction (6). In our case, the most common symptom was dyspnea and hemoptysis.

In general, the role of imaging studies is limited. Occasionally, chest $X$-ray reveals signs of tracheal lesions on the lateral view, particularly, and, in some cases, thoracic CT shows tumorous growth in the trachea and large airways (7). Pulmonary function test is helpful in showing the signs of variable or fixed tracheal obstructions. In our case, tracheal lesion was not seen on chest-X ray, which showed a lesion at the distal trachea. Yildirim et al. (8) reported a case with TP occupied $80 \%$ of tracheal lumen and a mass was shown on thoracic CT at the distal trachea, similar to our case. Involvement of lower airways and lung is very rare. Lung lesions occur in less than $1 \%$ patients. In a study, the authors analyzed eight RRP pa- tients of CT scans and found that the most common finding was the combination of intratracheal polypoid lesions and multiple pulmonary nodules, many of which were cavitated (9). In another case report, CT examination revealed mucosal nodules protruding to the lumen of the trachea. Similar lesions were also seen in the vocal cord, and multiple nodules were observed in both lungs (10).

Although TPs are known to be benign, very low risk for malignant transformation still exists. The mechanism of transformation from RRP to a squamous-cell carcinoma remains unclear. Malignant degeneration to squamouscell carcinoma is reported in 3 to $5 \%$ of all cases of TP (11). Malignant transformation of TP is associated with HPV types, radiotherapy, chemotherapy with bleomycin, and a history of smoking (12). In addition, HPV-6 and 11 are the most commonly identified types in cases of TP and are associated with a low risk of carcinomatous transformation. However, HPV-16 and 18, occasionally in combination with types 31, 33 or 35, are associated with a higher risk of carcinomatous transformation (13).

Treatment of TPs is difficult and often requires recurrent endoscopic interventions and medical treatment. There are no therapeutic guidelines with head-to-head trials in the literature. Treatment modalities may vary according to the type, severity, number, and location of papilloma (7). Various endoscopy surgical methods are successfully used in the management of papillomas. Among these, excision by carbon dioxide laser is most commonly used in children, particularly $(3,14)$. Cryotherapy is also reported to be successful in cases with endobronchial obstruction $(8,15)$. If the lesions are limited to a small part of the bronchi or trachea, photodynamic therapy, yttrium aluminum garnet (YAG), laser vaporization and electrocautery or argon laser coagulation can be used, as in our case (16). Kamatsu and Takahashi (17) reported a TP case who was presented with recurrence after five years and was re-treated by potassium-titanyl-phosphate neodymium: YAG (KTP/Nd: YAG) laser. In our case, the lesions were resected with electrocautery and argon plasma coagulation and treated with balloon.

Local recurrence is common in papillomas after treatment. Therefore, close clinical follow-up these patients is of utmost importance. Long and Sani (18) reported adjuvant therapies (i.e., intralesional injection of cidofovir, and photodynamic therapy) were needed in 10\% of RRP cases. The current indications for adjuvant therapy after surgical interventions are the dissemination of the disease, and the rapid growth of the lesion causing airway compression $(19,20)$. In our case, the lesion was not large and 
there was no excessive obstruction of the tracheal lumen. Also, these lesions appeared for the first time. Therefore, we did not initiate an adjuvant therapy. The patient is still under follow-up at six months of diagnosis without recurrence.

In conclusion, TPs are rare entities, and clinicians should have a high index of suspicion in patients presenting with hemoptysis and obstructive symptoms along with a tracheotomy history. These patients should be also closely followed for possible recurrences and malignant transformation.

\section{CONFLICTS OF INTEREST}

None declared.

\section{AUTHOR CONTRIBUTIONS}

Concept - C.A., O.F.E., M.Y.Y., N.Y.; Planning and Design - C.A., O.F.E., M.Y.Y., N.Y.; Supervision - C.A., O.F.E., M.Y.Y., N.Y.; Funding - O.F.E., C.A.; Materials C.A., O.F.E., M.Y.Y.; Data Collection and/or Processing - C.A., O.F.E., M.Y.Y., N.Y.; Analysis and/or Interpretation - C.A., O.F.E.; Literature Review - C.A.; Writing C.A., M.Y.Y.; Critical Review - C.A.

\section{YAZAR KATKILARI}

Fikir - C.A., O.F.E., M.Y.Y., N.Y.; Tasarım ve Dizayn C.A., O.F.E., M.Y.Y., N.Y.; Denetleme - C.A., O.F.E., M.Y.Y., N.Y.; Kaynaklar - O.F.E., C.A.; Malzemeler C.A., O.F.E., M.Y.Y.; Veri Toplama ve/veya İşleme - C.A., O.F.E., M.Y.Y., N.Y.; Analiz ve/veya Yorum - C.A., O.F.E.; Literatür Taraması - C.A.; Yazıyı Yazan - C.A., M.Y.Y.; Eleştirel İnceleme - C.A.

\section{REFERENCES}

1. Valentino J, Brame CB, Studtmann KE, Manaligod JM. Primary tracheal papillomatosis presenting as reactive airway diseases. Otolaryngol Head Neck Surg 2002; 126:79-80. [CrossRef]

2. Miura H, Tsuchida $T$, Kawate $N$, Konaka C, Kato H, Ebihara Y. Asymptomatic solitary papilloma of the bronchus: review of occurrence in Japan. Eur Respir J 1993; 7:1073-7.

3. Naka Y, Nakao K, Hamaji Y, Nakahara M, Tsujimoto M, Nakahara K. Solitary squamous cell papilloma of the trachea. Ann Thorac Surg 1993; 1:189-93. [CrossRef]

4. Kosko JR, Dekay CS. Role of cesarean section in prevention of recurrent respiratory papillomatosis- is there one? Int J Pediatr Otorhinolaryngol 1996; 35:31-8. [CrossRef]
5. Rad MH, Alizadeh E, Ilkhanizadeh B. Recurrent laryngeal papillomatosis with bronchopulmonary spread in a 70 year-old man. Tuberk Toraks 2007; 55:299-302.

6. David PB, Owen L, Barret H, Burke C. Isolated tracheal papillomatosis-an infrequent cause of chronic cough. Respir Med Extra 2007; 3: 21-2. [CrossRef]

7. Harris K, Chalhoub M. Tracheal papillomatosis: what do we know so far? Chron Respir Dis 2011; 8: 233-5. [CrossRef]

8. Yıldırım F, Türk M, Demircan S, Akyürek N, Yurdakul AS. Tracheal Papilloma Treated with Cryotherapy and Interferon- $\alpha$ : A Case Report and Review of the Literature. Case Reports in Pulmonology. 2015 (2015), Article ID 356796

9. Marchiori E, Araujo Neto Cd, Meirelles GS, Irion KL, Zanetti G, Missrie I, et al. Laryngotracheobronchial papillomatosis: findings on computed tomography scans of the chest. J Bas Pneumol 2008; 34:1084-9.

10. Ağgünlü $L$, Erbaş $G$. Recurrent respiratory papillomatosis with lung involvement. Diagn Interv Radiol 2009; 15:935.

11. Ogata-Suetsugu S, Izumi M, Takayama K, Nakashima T, Inove $\mathrm{H}$, Nakanishi $\mathrm{Y}$. A case of multiple squamous cell papillomas of the trachea. Ann Thorac Cardiovasc Surg $2011 ; 17: 212-4$. [CrossRef]

12. Guillou L1, Sahli R, Chaubert P, Monnier P, Cuttat JF, Costa J. Squamous cell carcinoma of the lung in a nonsmoking, nonirradiated patient with juvenile laryngotracheal papillomatosis. Evidence of humanpapilloma virüs11 DNA in both carcinoma and papillomas. Am J Surg Pathol 1991; 15:891-8.

13. Lang TU, Khalbuss WE, Monaco SE, Pantanowitz L. Solitary tracheobronchial papilloma: cytomorphology and ancillary studies with histologic correlation. Cytojournal 2011 ; 8:6. [CrossRef]

14. Siogren PP, Sidman JD. Use of the carbon dioxide laser for tracheobronchial lesions in children. JAMA Otolaryngol Head Neck Surg 2013; 139:231-5. [CrossRef]

15. Yıldız F, Sever M, Kömüs N, Uçan S, Sivrikoz O. Endobronchial solitary papilloma. Turk Respir J 2011; 12:165-7. [CrossRef]

16. Cömert SŞ, Parmaksız ET, Çağlayan B, Gülseven HT, Salepçi B, Fidan A. Typical carcinoid and benign endobronchial tumors cases treated with interventional bronchoscopic techniques. Solunum 2013; 15: 39-44. [CrossRef]

17. Komatsu T, Takahashi Y. Tracheal papilloma with exceptionally longer interval of recurrence. Asian J Surg 2007; 30:88-90. [CrossRef] 
18. Yeoh TL, Sani A. Recurrent respiratory papillomatozis. Asian J Surg 2003; 26:112-6.

19. Stamataki S, Nikolopoulos S, Korres D, Felekis A, et al. Juvenile recurrent respiratory papillomatosis: still a mystery disease with difficult management. Head Neck 2007; 29:155-62. [CrossRef]
20. Derkay CS, Wiatrak B. Recurrent respiratory papillomatosis: a review. Laryngoscope 2008; 118:1236-47. [CrossRef] 